\title{
Acute Coronary Syndrome, Antiplatelet Therapy, and Bleeding: A Clinical Perspective
}

\author{
Gregorio Tersalvi ${ }^{1,2, *,+} \oplus$, Luigi Biasco ${ }^{3,4,+}$, Giacomo Maria Cioffi ${ }^{1,5}(\mathbb{D}$ and \\ Giovanni Pedrazzini 1,4,* \\ 1 Division of Cardiology, Fondazione Cardiocentro Ticino, 6900 Lugano, Switzerland; \\ giacomomaria.cioffi@bluewin.ch \\ 2 Department of Internal Medicine, Hirslanden Klinik St. Anna, 6006 Lucerne, Switzerland \\ 3 Azienda Sanitaria Locale Torino 4, Ospedale di Ciriè, 10073 Ciriè, Italy; luigi.biasco@gmail.com \\ 4 Department of Biomedical Sciences, University of Italian Switzerland, 6900 Lugano, Switzerland \\ 5 Department of Cardiology, Kantonsspital Luzern, 6000 Lucerne, Switzerland \\ * Correspondence: tersalvi@gmail.com (G.T.); giovanni.pedrazzini@cardiocentro.org (G.P.) \\ + Gregorio Tersalvi and Luigi Biasco equally contributed to this manuscript.
}

Received: 16 June 2020; Accepted: 29 June 2020; Published: 1 July 2020

\begin{abstract}
Inhibition of platelet function by means of dual antiplatelet therapy (DAPT) is the cornerstone of treatment of acute coronary syndrome (ACS). While preventing ischemic recurrences, inhibition of platelet function is clearly associated with an increased bleeding risk, a feared complication that may lead to significant morbidity and mortality. Since bleeding risk management is intrinsically associated with therapeutic adjustments undertaken during the whole clinical history of patients with acute coronary syndrome, single decisions taken from the very first day to years of follow-up might be decisive. This review aims at providing a clinically oriented, patient-tailored approach in reducing the risk and manage bleeding complications in ACS patients treated with DAPT. The steps in clinical decision making from the day of ACS to follow-up are analyzed. New treatment strategies to enhance the safety of DAPT are also described.
\end{abstract}

Keywords: dual antiplatelet therapy; bleeding; acute coronary syndrome; high bleeding risk; clopidogrel; prasugrel; ticagrelor; tailored therapy; P2Y12 inhibition

\section{Introduction}

Inhibition of platelet function following acute coronary syndrome (ACS) using dual antiplatelet therapy (DAPT) is aimed at preventing the occurrence of short- and long-term thrombotic complications.

In the first weeks after percutaneous revascularization DAPT reduces the risk of stent thrombosis, a potentially fatal event occurring as a result of inflammation and endothelial damage associated with mechanical insult during percutaneous coronary interventions (PCI), the so-called "stent protective effect" [1,2]. As time passes by, the aim of DAPT changes. Long-term therapy has been shown to mitigate the risk of subsequent ischemic events not only associated with culprit lesions/vessels, but also arising from the progression of atherosclerosis, also known as the "patient protective effect" [3,4].

Several antithrombotic drugs have been proposed over time aimed at providing the highest thrombotic protection while counterbalancing the associated hemorrhagic risks. According to European guidelines [5-7] the use of the two most recent and potent P2Y12 inhibitors (i.e., prasugrel, ticagrelor) on top of aspirin with or without PCI is nowadays recommended in all suitable ACS patients [8,9]. A greater reduction of the thrombotic risk comes at the price of an increase in major bleedings, occurring in around 1-8\% during the first year after DAPT initiation [8-13]. Even less severe bleeding might increase mortality via indirect mechanisms such as unplanned hospitalization, need for urgent 
procedures, and DAPT discontinuation [14]. As a result, bleeding is directly associated with increased mortality and indirectly linked to recurrence of ischemic events such as myocardial infarction (MI) and stroke [15-20].

Even in the presence of clear and precise guidelines and dedicated scores, a wise choice of type and length of DAPT therapy is challenging. Overall, DAPT should be tailored over time on the basis of the clinical profile, the type of intervention, patient's tolerance, comorbidities, and occurrence of bleedings events [21]. Tailoring antiplatelet therapy intensity to patient risk improves not only clinical outcomes, such as morbidity and mortality, but it also impacts on health utility and could produce cost savings [22].

The purpose of this review is to offer an update on current literature and provide a clinically oriented, patient-tailored approach in reducing the risk and manage bleeding complications in ACS patients treated with DAPT (Figure 1).

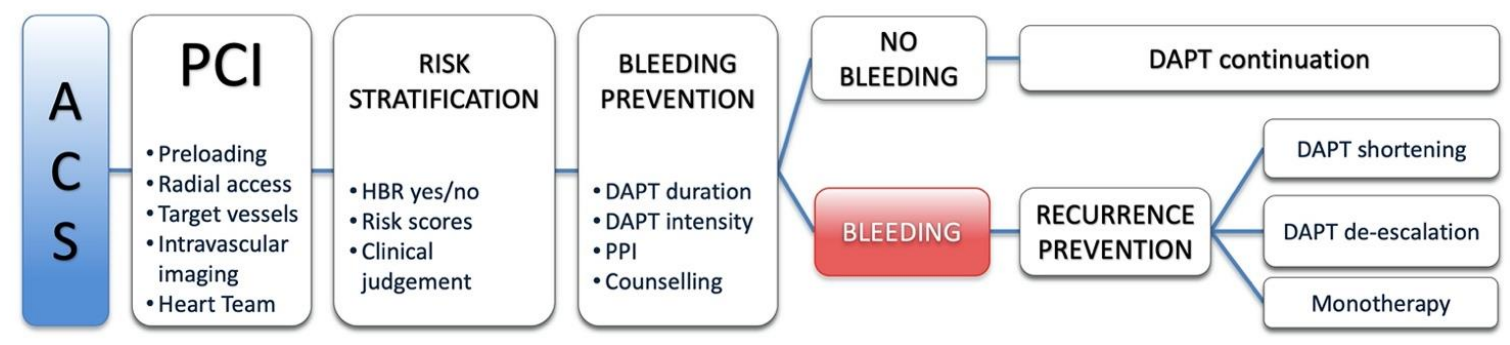

Figure 1. Critical points in decision making when choosing an antiplatelet strategy and managing related bleedings. PCI, percutaneous coronary intervention; DAPT, dual antiplatelet therapy; ACS, acute coronary syndrome; HBR, high bleeding risk; PPI, proton pump inhibitors.

\section{Definition of Bleeding and Prognostic Significance}

The definition and classification of bleeding severity has always suffered from extensive variability with several classifications and study-specific definitions proposed over time [23], making interstudy comparisons challenging. To limit the degree of heterogeneity, the Bleeding Academic Research Consortium (BARC) proposed a classification system which has become widely accepted as a common framework for reporting bleedings (Table 1) [24]. More recently, a consensus definition to identify patients at high bleeding risk (HBR) was proposed, a peculiar subgroup either excluded or underrepresented in clinical trials [25].

Table 1. Bleeding Academic Research Consortium definition for bleeding (modified from Mehran et al. [24]). CABG, coronary artery bypass grafting; IV, intravenous.

\begin{tabular}{|c|c|}
\hline Type 0 & No bleeding \\
\hline Type 1 & Bleeding that is not actionable and does not cause the patient to seek treatment \\
\hline Type 2 & $\begin{array}{l}\text { Any clinically overt sign of hemorrhage that "is actionable" and requires diagnostic studies, } \\
\text { hospitalization, or treatment by a health care professional }\end{array}$ \\
\hline Type 3 & $\begin{array}{l}\text { a. Overt bleeding plus hemoglobin drop of } 3 \text { to }<5 \mathrm{~g} / \mathrm{dL} \text { (provided hemoglobin drop is related to } \\
\text { bleed); transfusion with overt bleeding } \\
\text { b. Overt bleeding plus hemoglobin drop }<5 \mathrm{~g} / \mathrm{dL} \text { (provided hemoglobin drop is related to bleed); } \\
\text { cardiac tamponade; bleeding requiring surgical intervention for control; bleeding requiring IV } \\
\text { vasoactive agents } \\
\text { c. Intracranial hemorrhage confirmed by autopsy, imaging, or lumbar puncture; intraocular bleed } \\
\text { compromising vision }\end{array}$ \\
\hline Type 4 & CABG-related bleeding within $48 \mathrm{~h}$ \\
\hline Type 5 & $\begin{array}{c}\text { a. Probable fatal bleeding } \\
\text { b. Definite fatal bleeding (overt or autopsy or imaging confirmation) }\end{array}$ \\
\hline
\end{tabular}


The negative prognostic impact of bleeding has been reported in a series of large clinical trials in ACS patients. The mechanisms linking bleeding to increased mortality are heterogeneous [26]. While intracranial or massive bleeding exerts a direct life threatening effect due to fatal brain damage or sudden cardiocirculatory collapse, other forms of less severe bleeding increase the risk of death via indirect mechanisms. The need for transfusions of red blood cells, by increasing inflammation and apoptosis, is a possible link between bleeding and mortality [27]. Other medical procedures required to manage bleeding may also increase the rates of complications. Furthermore, bleeding is a major driver of unplanned DAPT discontinuation, which increases the risk of ischemic recurrences [28]. Besides DAPT, other key cardioprotective medications like beta-blockers, Renin-Angiotensin-Aldosterone System (RAAS) blockers or statins are often discontinued after bleeding, further increasing the risk for recurrent events [29].

Reflecting the importance of the prognostic association between bleeding and mortality, current guideline recommendations advocate for bleeding avoidance strategies starting from the time of revascularization and continuing in the long-term after the acute clinical presentation [7].

\section{Risk Stratification}

Quantifying patients' bleeding risk through the assessment of their clinical characteristics is crucial as it determines the type and length of DAPT regimen. Recently, the Academic Research Consortium for High Bleeding Risk (ARC-HBR) defined HBR as risk of BARC 3 or 5 bleeding $\geq 4 \%$ or of intracranial hemorrhage $\geq 1 \%$ at 1 year [25]. Clinical criteria identifying HBR are older age, kidney and/or liver disease, active cancer, anemia, low platelet count, previous stroke, prior bleeding, recent trauma or surgery, and use of oral anticoagulants and/or NSAIDs [7,25,30-32]. By accounting for these variables, the ACR-HBR score allows a dichotomic stratification of patients in HBR and non-HBR [25]. Several other scores have been proposed, a summary of their key points is provided in Table 2. Importantly, many variables coincide as risk factors for bleeding as well as ischemic events (e.g., older age, male gender, high creatinine, low hemoglobin) [33]. As a result, physicians must often grapple with patients at high risk with a narrow therapeutic window in both ways.

Table 2. Risk scores used to estimate bleeding risk in patients with coronary artery disease on antiplatelet therapy. * In the ACTION score, a lower body weight was associated to higher bleeding risk, with maximum risk when body weight was $\leq 50 \mathrm{~kg}$. In the PARIS score, a body mass index $<25$ or $\geq 35$ was associated to higher bleeding risk. ACS, acute coronary syndrome; ATT, antithrombotic treatment; $\mathrm{BP}$, blood pressure; CAD, coronary artery disease; ECG, electrocardiogram; HF, heart failure; NSTEACS, non-ST-elevation acute coronary syndrome; NSTEMI, non-ST-elevation myocardial infarction, OAT, oral anticoagulation therapy; STEMI, ST-elevation myocardial infarction; WBC, white blood cells.

\begin{tabular}{|c|c|c|c|c|c|c|}
\hline & $\underset{[34]}{\operatorname{ACTION}}$ & $\begin{array}{l}\text { CRUSADE } \\
\text { [35] }\end{array}$ & $\begin{array}{c}\text { ACUITY- } \\
\text { HORIZONS [36] }\end{array}$ & $\begin{array}{l}\text { PARIS } \\
\text { [37] }\end{array}$ & $\begin{array}{l}\text { PRECISE- } \\
\text { DAPT [38] }\end{array}$ & $\begin{array}{c}\text { BleeMACS } \\
\text { [39] }\end{array}$ \\
\hline Population & $\begin{array}{l}\text { STEMI, } \\
\text { NSTEMI }\end{array}$ & NSTEACS & ACS & $\begin{array}{c}\text { Stable } \\
\text { CAD, ACS }\end{array}$ & $\begin{array}{c}\text { Stable } \\
\text { CAD, ACS }\end{array}$ & ACS \\
\hline \multicolumn{7}{|l|}{ Variables } \\
\hline Age & $x$ & & $x$ & $x$ & $x$ & $x$ \\
\hline Gender & $x$ & $x$ & $x$ & & & \\
\hline Heart rate & $x$ & $x$ & & & & \\
\hline $\begin{array}{l}\text { Systolic BP or } \\
\text { hypertension }\end{array}$ & $x$ & $x$ & & & & $x$ \\
\hline Hemoglobin & $x$ & & $x$ & $x$ & $x$ & $x$ \\
\hline Hematocrit & & $x$ & & & & \\
\hline WBC & & & $x$ & & $x$ & \\
\hline Creatinine & $x$ & $x$ & $x$ & $x$ & $x$ & $x$ \\
\hline
\end{tabular}


Table 2. Cont.

\begin{tabular}{|c|c|c|c|c|c|c|}
\hline & $\begin{array}{c}\text { ACTION } \\
{[34]}\end{array}$ & $\begin{array}{l}\text { CRUSADE } \\
{[35]}\end{array}$ & $\begin{array}{c}\text { ACUITY- } \\
\text { HORIZONS [36] }\end{array}$ & $\begin{array}{c}\text { PARIS } \\
\text { [37] }\end{array}$ & $\begin{array}{l}\text { PRECISE- } \\
\text { DAPT [38] }\end{array}$ & $\begin{array}{c}\text { BleeMACS } \\
\text { [39] }\end{array}$ \\
\hline Diabetes & $x$ & $x$ & & & & \\
\hline Smoking & & & & $x$ & & \\
\hline Body mass* & $x$ & & & $x$ & & \\
\hline $\mathrm{HF}$ & $x$ & $x$ & & & & \\
\hline Vascular disease & $x$ & $x$ & & & & $x$ \\
\hline Malignancy & & & & & & $x$ \\
\hline OAT & $x$ & & & $x$ & & \\
\hline ECG changes & $x$ & & & & & \\
\hline ATT & & & $x$ & & & \\
\hline Type of ACS & & & $x$ & & & \\
\hline Prior bleeding & & & & & $x$ & $x$ \\
\hline Bleeding outcome & In-hospital & In-hospital & 30 days & 2 years & 12 months & 12 months \\
\hline
\end{tabular}

European guidelines gave an intermediate grade recommendation for the use of risk scores such as the DAPT and the PRECISE-DAPT (class Ilb recommendation, level of evidence A) to guide antiplatelet therapy after PCI [7]. However, none of these risk prediction models have been prospectively tested in the setting of randomized controlled trials (RCT). In our clinical practice, scores do not add valuable information in addition to clinical judgement when all above parameters are taken into consideration. Thus, when assessing the risk, clinical judgment should be carefully exercised.

\section{Bleeding Prevention in Different DAPT Phases}

Bleeding risk management is intrinsically associated with therapeutic choices taken during the whole clinical history of patients with ACS. Thus, single decisions taken from the very first day to years of follow-up after an ACS might be decisive.

\subsection{Pre-Treatment}

In invasively managed ACS, pre-treatment refers to the practice of initiating DAPT before invasive coronary angiography and percutaneous treatment [40].

The rationale of P2Y12 receptor blocker administration before PCI in ACS arises from the observation that the risk of early thrombotic complications, such as re-infarction or acute stent thrombosis, is directly related to the level of platelet reactivity. This clearly represents an attractive option when either an emergent or urgent/elective approach is undertaken. Nonetheless, exposure to a more potent platelet inhibition might be useless in patients in whom an ACS is ruled out after angiography (e.g., myocarditis, tako-tsubo cardiomyopathy, non-ischemic myocardial injury) and possibly harmful in of those referred to surgical revascularization, a small but clinically challenging subgroup of ACS patients [41]. In addition, pre-treatment often defines the type of P2Y12 inhibitor that will be prescribed to patients even after discharge, highlighting the importance of a wise choice in forecast of a long-term strategy.

In ST-elevation myocardial infarction (STEMI), there is limited evidence with respect to when the P2Y12 inhibitor should be initiated [42-46]. European guidelines suggest that the earliest possible administration may be preferable (not compulsory) to achieve rapid platelet's inhibition. However, in cases in which the STEMI diagnosis is not clear, delaying P2Y12 inhibitor administration until coronary anatomy is known should be considered [6]. In non-ST-elevation myocardial infarction (NSTEMI), European guidelines discourage pre-treatment with Prasugrel [5,47,48]. Regarding the other two P2Y12 inhibitors, recent data from SCAAR (Swedish Coronary Angiography and Angioplasty Registry) 
suggested no benefit of a pre-treatment strategy with ticagrelor or clopidogrel on 30-day and 1-year mortality while highlighting a significant increase in bleedings [49].

In summary, the role of pre-treatment with P2Y12 inhibitors in ACS is still controversial. It might increase bleeding risk without giving major benefits on short- and long-term clinical outcomes.

Concordant to European Society of Cardiology (ESC) guidelines, a wise approach might be to perform routine pre-treatment in STEMI, except for patients with unclear diagnosis or high/very high bleeding risk, and to wait to administer the loading dose of P2Y12 inhibitor in NSTEMI only after defining coronary anatomy.

\subsection{Percutaneous Coronary Interventions}

In patients with ACS undergoing PCI, a wise selection of procedural strategy might significantly reduce the short- and long-term bleeding risk.

The transition from the femoral to the radial access has dramatically reduced the risk of access site major bleedings, surgical access site repair, transfusion of blood products, death, MI, or stroke $[50,51]$ while maintaining the level of intraprocedural anticoagulation and platelet inhibition substantially stable. Thus in all PCIs the radial artery should be considered the access of choice, and, given its advantages, interest is increasing in shifting from the femoral to the radial as an ancillary access in structural interventions [52].

Even the procedural strategy might indirectly impact on the long-term bleeding risk. Extensive percutaneous revascularizations in multivessel disease (or in prior failures of PCIs with need of stent in stent implantation), adoption of complex two stents techniques in particular when tackling left main lesions, treatment of calcific lesions with associated stent under-expansion, malapposition and small vessel disease are all associated with an increased risk of long-term ischemic events. Interestingly, those challenging anatomical characteristics are often recognized in elderly patients with associated comorbidities such as diabetes, advanced vascular disease or renal impairment, a group with an intrinsically associated HBR [30]. Procedural strategies might then aim at performing percutaneous revascularization targeting only those segments with a clear prognostic and functional relevance, choosing second and third generation coronary stents approved for short-term DAPT and optimizing the result of stent implantation with the support of intravascular imaging. In our routine, doubtful cases undergo Heart Team discussion to verify whether surgery might provide a more complete revascularization and a lower long-term exposure to bleeding risk at a reasonable surgical risk.

\subsection{Stent Protection (Short-Term)}

Following the guideline-recommended treatment interval of 12 months in ACS [7], much debate remains around the optimal antiplatelet therapy regimen and duration.

During the first weeks after stent implantation, DAPT reduces the risk of stent thrombosis that occurs as a result of inflammation following the mechanical insult of PCI [1,2]. After this, DAPT has been shown to mitigate the risk of recurrent ischemic events associated with progression of coronary artery disease even beyond culprit-related lesions [3,4]. While DAPT does not limit the progression of atherosclerosis, platelet inhibition protects against consequences of spontaneous coronary plaque erosion or rupture [53]. Whereas a prolongation of DAPT beyond 1 year would therefore seem reasonable to reduce ischemic risk, continued antiplatelet therapy prolongs exposure to the associated bleeding risk $[54,55]$. Thus, potential benefits of reducing DAPT duration were evaluated in recent large RCTs (Table 3). Beside length of exposure, different DAPT regimens might impact on the associated bleeding risk. Pushing the boundaries of platelet inhibition to prevent ischemic events with more potent $\mathrm{P} 2 \mathrm{Y} 12$ inhibitors is clearly associated to an increase in non-related to coronary artery bypass grafting major bleeding as observed in both PLATO [9] and TRITON-TIMI 38 [8] trials where prasugrel and ticagrelor where compared to clopidogrel, respectively. The only two large trials performing a direct comparison of prasugrel-based and ticagrelor-based DAPT in ACS patients did not show any difference in bleeding events between the two DAPT regimens $[56,57]$. 


\subsection{Patient Protection (Long-Term)}

In the PEGASUS-TIMI 54 trial [58], a prolonged DAPT with ticagrelor (90 mg twice daily or $60 \mathrm{mg}$ twice daily) and low-dose aspirin 1 to 3 years after MI showed a significant reduction in cardiovascular death, MI, or stroke compared to aspirin and placebo on a median follow-up of 33 months. As a drawback, the rates of major bleeding were higher with ticagrelor $(2.60 \%$ with $90 \mathrm{mg}$ and $2.30 \%$ with $60 \mathrm{mg}$ ) than with placebo $(1.06 \% ; p<0.001$ for each dose vs. placebo). Similar results were obtained in the DAPT trial [4], in which continuation of DAPT with clopidogrel or prasugrel for more than 12 months after coronary stenting showed a reduction in non-fatal ischemic events, but an increase in major bleeding compared to single antiplatelet therapy (SAPT) with aspirin and placebo.

Current evidence suggests that bleeding risk is proportionally related to the DAPT duration both within and beyond 1 year of treatment duration. Extension of DAPT should therefore be individualized based on patients' ischemic risk and should be avoided when the risk of bleeding overshadows the likelihood of ischemic recurrences. A recent retrospective study of pooled data of RCTs showed that patients who were treated with complex PCI had a higher risk of ischemic events but benefitted from long-term DAPT only if HBR features were not present. These data suggest that, when bleeding and ischemic risk are concordant, the first should guide decision-making on DAPT duration [59]. Thus, in patients presenting with ACS and at HBR a priori, a strategy of short DAPT may be an effective solution.

\section{Management of Bleeding during DAPT}

\subsection{General Approach}

DAPT-associated bleeding represents a clinical challenge in a field where no clear evidence is available. Overall, concurrent antiplatelet therapy is considered an important predictor of mortality and complications following a gastrointestinal, intracranial, or trauma-related bleeding [63-66].

Table 4 shows a stepwise approach the management of DAPT related bleedings according to current European guidelines [7].

Decisions regarding the acute therapy and whether to stop or continue DAPT are made on an individual patient basis, based primarily on the severity of bleeding, as this is the major predictor of morbidity and mortality $[20,67]$. A clear need to balance likelihood and consequences of therapy discontinuation according to the degree of the hemorrhagic event also has to be considered.

In the acute setting, patients presenting trivial or mild bleeding do not require specific therapy, but may profit from adequate drug-adherence counselling, as well as adding a PPI in cases of gastrointestinal (GI) bleeding. If the bleeding is moderate, its cause should be identified and treated (e.g., peptic ulcer, hemorrhoidal plexus, epistaxis, neoplasm). For severe and life-threatening bleeding, an urgent treatment of its source must be obtained together with red blood cells and platelet transfusions [7]. 
Table 3. Randomized controlled trials comparing different durations of dual antiplatelet therapy. ASA, aspirin; BARC, Bleeding Academic Research Consortium; Mos, months; TIMI, Thrombolysis in Myocardial Infarction; $\vee$, statistically significant reduction in outcome in experimental group compared to control group; $\wedge$, statistically significant increase in outcome in experimental group compared to control group; $=$, no statistical difference in outcome between the two groups.

\begin{tabular}{|c|c|c|c|c|c|c|c|c|c|}
\hline Trial & $\mathbf{N}$ & $\begin{array}{l}\text { Experimental } \\
\text { Group }\end{array}$ & Mos & Control Group & Mos & Ischemic Outcome & Results & $\begin{array}{l}\text { Bleeding } \\
\text { Outcome }\end{array}$ & Results \\
\hline CURE [3] & 12,562 & ASA + Clopidogrel & $3-12$ & ASA + Placebo & $3-12$ & $\begin{array}{l}\text { Death from cardiovascular } \\
\text { causes, non-fatal myocardial } \\
\text { infarction, or stroke }\end{array}$ & $\vee$ & TIMI & $\wedge$ \\
\hline PLATO [9] & 18,624 & ASA + Ticagrelor & $3-12$ & $\begin{array}{c}\text { ASA + } \\
\text { Clopidogrel }\end{array}$ & $3-12$ & $\begin{array}{l}\text { Death from vascular causes, } \\
\text { myocardial infarction, or stroke }\end{array}$ & $\vee$ & TIMI & $=$ \\
\hline TRITON [8] & 13,608 & ASA + Prasugrel & $6-15$ & $\begin{array}{c}\text { ASA + } \\
\text { Clopidogrel }\end{array}$ & $6-15$ & $\begin{array}{l}\text { Death from cardiovascular } \\
\text { causes, non-fatal myocardial } \\
\text { infarction, or non-fatal stroke }\end{array}$ & $\vee$ & TIMI & $=$ \\
\hline TWILIGHT [60] & 7119 & $\begin{array}{c}\text { Ticagrelor + ASA } \\
\text { Ticagrelor + Placebo }\end{array}$ & $\begin{array}{l}3 \\
9\end{array}$ & Ticagrelor + ASA & 12 & $\begin{array}{c}\text { Death from any cause, non-fatal } \\
\text { myocardial infarction, } \\
\text { or non-fatal stroke }\end{array}$ & $=$ & BARC $2,3,5$ & $\vee$ \\
\hline $\begin{array}{c}\text { GLOBAL } \\
\text { LEADERS [61] }\end{array}$ & 15,991 & $\begin{array}{l}\text { Ticagrelor + ASA } \\
\text { Ticagrelor }\end{array}$ & $\begin{array}{c}1 \\
23\end{array}$ & $\begin{array}{l}\text { Ticagrelor/ } \\
\text { Clopidogrel + } \\
\text { ASA } \\
\text { ASA }\end{array}$ & $\begin{array}{l}12 \\
12\end{array}$ & $\begin{array}{l}\text { All-cause mortality or non-fatal } \\
\text { myocardial infarction }\end{array}$ & $=$ & BARC 3,5 & $\vee$ \\
\hline TICO [62] & 3056 & $\begin{array}{l}\text { Ticagrelor + ASA } \\
\text { Ticagrelor }\end{array}$ & $\begin{array}{l}3 \\
9\end{array}$ & Ticagrelor + ASA & 12 & $\begin{array}{l}\text { Death, myocardial infarction, } \\
\text { stent thrombosis, stroke, and } \\
\text { target vessel revascularization }\end{array}$ & $=$ & TIMI & $\vee$ \\
\hline
\end{tabular}


Table 4. Definition and management of bleeding in patients on dual antiplatelet therapy (modified from European Guidelines [7]). DAPT, dual antiplatelet therapy; GI, gastrointestinal; GU, genitourinary; Hb, hemoglobin; i.v., intravenous; Plt, Platelets; PPI, proton pump inhibitor; RBC, red blood cell; SAPT, single antiplatelet therapy.

\begin{tabular}{|c|c|c|c|c|}
\hline Severity Grade & Definition & Examples & DAPT Management & Other Recommendations \\
\hline Trivial & $\begin{array}{l}\text { Any bleeding not requiring } \\
\text { medical intervention or } \\
\text { further evaluation }\end{array}$ & $\begin{array}{l}\text { Skin bruising, ecchymosis, } \\
\text { self-resolving epistaxis, minimal } \\
\text { conjunctival bleeding }\end{array}$ & Continue DAPT & $\begin{array}{c}\text { Reassure the patient } \\
\text { Identify preventive strategies } \\
\text { Drug-adherence counselling }\end{array}$ \\
\hline Mild & $\begin{array}{l}\text { Any bleeding that requires } \\
\text { medical attention without } \\
\text { requiring hospitalization }\end{array}$ & $\begin{array}{l}\text { Not self-resolving epistaxis, moderate } \\
\text { conjunctival bleeding, GU or GI } \\
\text { bleeding without significant blood } \\
\text { loss, mild hemoptysis }\end{array}$ & $\begin{array}{c}\text { Continue DAPT } \\
\text { Consider shortening DAPT duration } \\
\text { Consider DAPT de-escalation }\end{array}$ & $\begin{array}{l}\text { Identify and treat } \\
\text { bleeding-related conditions } \\
\text { Add PPI if not present } \\
\text { Drug adherence counselling }\end{array}$ \\
\hline Moderate & $\begin{array}{c}\text { Any bleeding associated with a } \\
\text { significant blood loss }(>3 \mathrm{~g} / \mathrm{dL} \\
\mathrm{Hb} \text { ) and/or requiring } \\
\text { hospitalization, } \\
\text { hemodynamically stable and } \\
\text { not evolving }\end{array}$ & $\begin{array}{l}\text { GU, respiratory or GI bleeding with } \\
\text { significant blood loss or requiring } \\
\text { blood transfusion }\end{array}$ & $\begin{array}{c}\text { Consider switching from DAPT } \\
\text { to SAPT } \\
\text { Reinitiate DAPT as soon as } \\
\text { deemed safe } \\
\text { Consider DAPT de-escalation } \\
\text { Consider shortening DAPT duration }\end{array}$ & $\begin{array}{c}\text { Identify and treat } \\
\text { bleeding-related conditions } \\
\text { i.v. PPI if GI bleeding } \\
\text { Drug adherence counselling }\end{array}$ \\
\hline Severe & $\begin{array}{l}\text { Any bleeding requiring } \\
\text { hospitalization, associated with } \\
\text { a severe blood loss }(>5 \mathrm{~g} / \mathrm{dL} \\
\mathrm{Hb}) \text {, hemodynamically stable } \\
\text { and not rapidly evolving }\end{array}$ & $\begin{array}{l}\text { Severe GU, respiratory or } \\
\text { GI bleeding. }\end{array}$ & $\begin{array}{c}\text { Consider switching from DAPT } \\
\text { to SAPT } \\
\text { If bleeding persists despite treatment, } \\
\text { consider stopping APT } \\
\text { Re-evaluate need of APT once } \\
\text { bleeding has ceased } \\
\text { Consider shortening DAPT duration } \\
\text { Consider DAPT de-escalation }\end{array}$ & $\begin{array}{c}\mathrm{RBC} \text { if } \mathrm{Hb}<7-8 \mathrm{~g} / \mathrm{dL} \\
\text { Consider Plt transfusion } \\
\text { Urgent treatment of bleeding } \\
\text { source if possible } \\
\text { i.v. PPI if GI bleeding }\end{array}$ \\
\hline Life-threatening & $\begin{array}{l}\text { Any severe active bleeding } \\
\text { putting patient's life } \\
\text { immediately at risk }\end{array}$ & $\begin{array}{l}\text { Massive overt GU, respiratory or GI } \\
\text { bleeding, active intracranial, spinal or } \\
\text { intraocular hemorrhage, or any } \\
\text { bleeding causing } \\
\text { hemodynamic instability }\end{array}$ & $\begin{array}{l}\text { Immediately discontinue all APT } \\
\text { Re-evaluate need of APT once } \\
\text { bleeding has ceased. }\end{array}$ & $\begin{array}{c}\text { Fluid replacement } \\
\text { RBC and Plt transfusion } \\
\text { Urgent treatment of bleeding } \\
\text { source if possible } \\
\text { i.v. PPI if GI bleeding }\end{array}$ \\
\hline
\end{tabular}




\subsection{Gastrointestinal Bleeding}

The most common serious DAPT related bleeding complication after PCI is GI haemorrage $[68,69]$.

Aspirin causes GI bleeding due to its direct inhibition of Cyclooxygenase-1, thus reducing the endothelial protective effect of prostaglandins. P2Y12 inhibitors are believed not to be directly ulcerogenic, but to impair ulcer healing by blocking platelet aggregation, angiogenesis, and endothelial proliferation [70]. Ticagrelor and prasugrel have been associated with higher risk of GI bleeding compared to clopidogrel $[8,69]$.

GI bleeding in patients with recent ACS and/or PCI represents a great therapeutic challenge due to its insidious presentation. The need to attain hemostasis often requires the premature discontinuation of antithrombotic therapies. In addition, acute bleeding itself leads to platelet activation and creation of a prothrombotic milieu. These two factors may explain the increase in ischemic risk in patients with GI bleeding receiving DAPT after ACS [71].

Often, GI bleeding might be only suspected in a patient with a progressive hemoglobin drop without overt bleeding source. Endoscopy is often crucial, after lesion identification, epinephrine injection, sclerotherapy, and metal clip placement [72] can effectively solve bleeding. In emergent cases, endovascular angiography is an effective and safe alternative to surgical intervention for patients whose GI bleeding is refractory to medical and endoscopic treatment [73] When GI bleeding is caused by diffuse lesions or super-selective catheterization is not possible, vasopressin infusion may be the only remaining therapeutic option, in particular in low GI bleedings [74] with a success rate of 59-90\% [75]. Efficacy of octreotide in the prevention of recurrent bleeding from gastrointestinal angiodysplasia has been also reported and is currently used in practice [76].

If endoscopy shows no active bleeding in patients with suspected upper GI bleeding, continuing DAPT is recommended [7,77], while a short interruption of aspirin (three days) should be considered [7,77], (preferably with continuation of P2Y12 inhibitor if feasible) when an active source is found. In overt lower GI bleeding, P2Y12 can be stopped for a maximum of 7 days, whilst aspirin should be continued [78]. Importantly, in patients with a recent ( $<90$ days) ACS or percutaneous intervention (<30 days), DAPT should be continued [78]. While not often specified by current guidelines, DAPT discontinuation should be preferentially considered in setting with 24/7 cath lab facility availability to timely treat potential recurrent ischemic events, in particular in patients with recent ( $<30$ days) PCI.

To reduce the risk of further GI bleeding, pharmacologically limiting the gastric acid secretion with the use of proton pump inhibitors (PPI) has been demonstrated to exert a protective effect [79]. Based on the assumption that the benefit of PPI prescription outweighs its harm, the 2017 ESC focused update on DAPT recommends prescription of PPI therapy to all patients receiving DAPT [7].

\subsection{Intracranial Bleeding}

Intracranial bleeding (ICB) represents the most serious DAPT-associated adverse event. Different locations of ICB are associated with different recurrent rates and disabilities. ICB are classified as lobar (cerebral cortex and underlying white matter) or deep (basal ganglia, thalamus, brainstem), with recurrence rates of $15.7 \%$ and $3.4 \%$, respectively [80]. In two recent prospective observational studies on patients with ICB, antiplatelet therapy on admission was associated with a higher 24-h [65], in-hospital [64], and 3-month [65] mortality rate compared to naïve patients.

In the acute setting, patients with ICB should be monitored and managed in an intensive care unit or dedicated stroke unit with high expertise level. All anticoagulant and antiplatelet drugs should be discontinued. While anticoagulation should be antagonized with proper agents, the specific management of patients on DAPT remains unclear, since platelet transfusions have shown inferiority to standard care regarding mortality [81]. If rupture of an intracranial aneurysm is evident, an interventional strategy with endovascular coiling has to be taken into consideration [82].

Enormous difficulties as to whether and when to restart medication are clearly evident in survivors [83]. In the large trials comparing new P2Y12 inhibitors to Clopidogrel, ICB was reported in only $0.3 \%$ of patients $[8,9]$. A meta-analysis including six observational studies on patients with 
ICB while on SAPT showed that only $43 \%$ of patients resumed antiplatelet therapy, and the timing of resumption, when available, varied widely from weeks to months [84].

Due to the scarce number of ICB events in DAPT trials, we can only presume that DAPT might be reinitiated after approximately 4 weeks, with aspirin plus clopidogrel, and continued until the minimum advised duration $[5,83]$. Clearly, reassessment of clinical status, need for DAPT (time from ischemic event/revascularization), and team discussion with neurologist/radiologist/cardiologist should guide the decision making process.

\section{Treatment Strategies after Bleeding}

\subsection{Restarting Antiplatelet Therapy}

The need for antiplatelet therapy must always be re-evaluated after a bleeding event and tailored on the patient's risk of recurrent ischemic and hemorrhagic events. Importantly, the risk of new ischemic events is increased after a recent ACS, especially during the first 3 months, and remains elevated up to 1 year [14]. After bleeding, no RCTs have assessed whether stopping or restarting one or both antiplatelet agents is the best choice. In patients with a recently implanted coronary stent, premature discontinuation of one or both antiplatelet agents (especially the P2Y12 inhibitor) has been shown to be the strongest predictor of stent thrombosis [85-87].

Recovery of platelet function after P2Y12 discontinuation depends on the magnitude of on-treatment platelet inhibition. On average, platelet reactivity returns to baseline by washout day 7 after prasugrel, day 5 after clopidogrel, and day $4-5$ after ticagrelor [88-90]. Thus, the risk of stent thrombosis increases with longer time off treatment, particularly more than 5 days, and if treatment is stopped within the first month after the procedure [85,86,91,92].

In a contemporary registry of over 5000 patients treated with $\mathrm{PCI}$, cardiovascular risk was significantly increased when DAPT cessation was due to non-compliance or bleeding [93].

The risk was highest for the first 7 days after discontinuation of DAPT, but still high within 30 days [93]. In a recent analysis of the PARIS registry, DAPT discontinuation due to bleeding occurred in $5 \%$ of the patients and it had higher subsequent mortality [28].

In summary, early discontinuation of DAPT is inevitably correlated to ischemic events and mortality. Thus, efforts should be made to continue antiplatelet therapy unless the bleeding is considered severe [7], this being the only case that justifies early DAPT interruption. Timing of DAPT resumption after clinically significant bleeding varied widely in clinical trials, from 2-3 days in GI bleeding to months after ICB [84]. Indications and timing of DAPT resumption should be evaluated on a patient basis, often achieving a consensus by multidisciplinary consensus. Due to the high ischemic risk already in the first days after interruption, DAPT should be discontinued under strict medical surveillance and restarted as soon as deemed safe. However, if the standard post-ACS DAPT with aspirin and a potent P2Y12 is considered hazardous, other strategies of optimization of antithrombotic therapy after a bleeding event are possible, which should be tailored on the individual patient's risk.

\subsection{Preventing Bleeding Recurrence}

Several therapeutic possibilities have been proposed to minimize the risk of bleeding in patients on DAPT. Three different strategies to modulate antiplatelet therapy that have been tested in clinical trials.

\subsubsection{DAPT Shortening}

Since bleeding risk is proportionally related to DAPT duration, reducing exposure to antiplatelet therapy has been hypothesized as a valid strategy to reduce bleedings.

Recent evidence has shown net benefits in the ischemic/bleeding balance for short ( $\leq 6$ months) vs. 12 months DAPT in patients with low ischemic risk [94,95]. Seven major RCTs published in recent years and evaluating a very short DAPT (1 or 3 months) after stenting as compared to 12-month therapy $[60,61,96-100]$ were analyzed together in a recent metanalysis [101]. Interestingly, very short 
DAPT yielded comparable rates of all-cause mortality, stent thrombosis, and major acute cardiovascular endpoints than 12 months DAPT. At the same time, very short DAPT was associated with reduced rates of major bleeding or any bleeding. Subgroup analyses showed consistent results for 1 vs. 3 month DAPT and for aspirin vs. P2Y12 inhibitor monotherapy following very short DAPT [101].

After a bleeding event, DAPT shortening is reasonable as these patients are mostly considered at high bleeding risk [38]. A 1-month DAPT regimen is considered safe after treatment with newer generation drug-eluting stents tested for 1-month DAPT [102].

\subsubsection{DAPT De-Escalation}

If bleeding occurs in patients on DAPT with prasugrel or ticagrelor, its replacement with clopidogrel ("de-escalation") may be another possible option.

Two aspects are of particular importance when considering a DAPT de-escalation strategy. First, timing of de-escalation should be carefully evaluated. If de-escalation is performed too close to the index event, there is a potential risk of increasing the rate of ischemic complications because the first weeks after ACS represent a vulnerable time window with high risk for ischemic recurrences or stent thrombosis $[23,103]$. Supported by current evidence, de-escalation is considered safe at the earliest 1 month after ACS [104].

The second important aspect is the considerable rate of high platelet reactivity with clopidogrel, occurring in up to $30 \%$ of patients [105] and representing a possible threat for thrombotic complications. This high patient-to-patient variability in platelet response to clopidogrel is multifactorial, being only partially explained by individual factors such as body weight, diabetes, renal failure, and old age [106-108], and also implicating genetic variants of liver cytochromes [109].

Platelet function tests (PFT) may be used as optional tool for deciding on a de-escalation from prasugrel or ticagrelor to clopidogrel [110].

In summary, de-escalation of DAPT is a valid strategy after a bleeding of low or moderate entity, since it represents an intermediate step between maintaining DAPT with potent P2Y12 inhibitors and switching to SAPT. The use of PFT to evaluate the patient's response to clopidogrel after switching might be considered as an additional tool to lower the risk of ischemic events.

\subsubsection{Monotherapy with P2Y12 Inhibitors}

The third strategy that has gained more and more evidence in the recent years is represented by the switch from DAPT to SAPT with P2Y12 inhibitors. In experimental models, the potent blockade of the P2Y12 receptor by prasugrel was able to attenuate the thromboxane A2-dependent pathways of platelet activation, which is the target of aspirin therapy [111]. Furthermore, in a recent RCT in 44 volunteers, ticagrelor-monotherapy and ticagrelor-based DAPT comparably affected hemostatic system activation [112]. These observations suggest that in the presence of potent P2Y12 blockade, adjunctive use of aspirin might have a limited impact.

Major RCTs evaluating P2Y12 monotherapy after short or very short DAPT and subsequent analyses of their results were described above. In general, P2Y12 monotherapy seems to reduce bleeding events without worsening of ischemic outcomes.

In the recent Ticagrelor With Aspirin or Alone in High-Risk Patients After Coronary Intervention (TWILIGHT) trial, ticagrelor monotherapy (following an initial course of uncomplicated DAPT for 3 months) reduced the rate of BARC 2,3, or 5 bleeding compared with standard DAPT consisting of ticagrelor and aspirin for 12 months. Of note, the majority of patients (64\%) included in the study had an ACS diagnosis at baseline. Anti-ischemic efficacy, evaluated using a composite endpoint of all-cause death, non-fatal MI, and stroke, did not differ among the randomized treatment groups, thus confirming the promising role of this regimen.

Monotherapy with P2Y12 inhibitors is usually the best choice after a moderate or severe GI bleeding event, because it avoids the ulcerogenic effects of aspirin on the gastric mucosa that may reiterate the bleeding. In addition, P2Y12 monotherapy may also be a good strategy in patients with 
mild but frequent bleeding events, in order to avoid complete suspension of antiplatelet therapy which carries ominous consequences [28].

At present, large clinical trials are ongoing with the aim to further clarify the role of aspirin-free strategies in high-risk patients after ACS (ULTIMATE-DAPT (NCT03971500), STOPDAPT-2-ACS (NCT03462498)). Importantly, physicians should keep in mind that SAPT with P2Y12 has been tested only after at least 1 month of DAPT.

\subsubsection{De-Escalating DAPT in Anticoagulated Patients}

Almost $6-8 \%$ of patients undergoing PCI have an indication for chronic oral anticoagulation (OAC) with vitamin $\mathrm{K}$ antagonists (VKA) or direct oral anticoagulants (DOAC), as a result of various conditions such as atrial fibrillation, mechanical heart valves and recent or recurrent venous thromboembolism [7]. However, adding antiplatelet agents to OAC increases non-fatal and fatal bleeding risk more than 3-fold compared with DAPT [113,114].

Therefore, clinical judgment and regular reassessment of the indication for OAC is essential.

As a golden rule, clopidogrel should be the P2Y12 inhibitor of choice, and triple therapy (DAPT plus OAC) should be kept as short as possible. Other possible strategies to avoid bleeding complications in this group of patients are preferring DOACs instead of VKA, targeting INR 2-2.5 when VKA is used, using the lower DOAC regimen tested in approval studies, and routine use of PPI [7].

In the case of a bleeding event in patients with DAPT and OAC, we suggest the de-escalation to dual therapy with OAC and Clopidogrel. If the patient is already on dual therapy, consider discontinuing antiplatelet therapy if deemed safe.

\section{Conclusions}

Since bleeding events have a major impact on prognosis in patients on DAPT after ACS, physicians' effort should be maximized to prevent this complication. This relies on a clinical and patient-tailored approach, that starts from the index hospitalization to the whole follow up. Accurate risk stratification, technical appropriateness of interventional procedures, wise choice of DAPT regimens, and duration are important steps in preventing bleedings event after ACS.

When occurring, timely management and a proper strategy in secondary prevention of bleeding events are decisive factors to reduce morbidity and mortality in these patients.

Importantly, when bleeding and ischemic risk are concordant, bleeding risk should inform decision making on DAPT.

Author Contributions: G.T. and L.B. drafted the manuscript. G.M.C. and G.P. critically reviewed the manuscript. All authors have read and agreed to the published version of the manuscript.

Funding: The authors received no financial support for the research, authorship, and/or publication of this article.

Conflicts of Interest: All authors have no conflict of interest to disclose.

\section{References}

1. Schömig, A.; Neumann, F.J.; Kastrati, A.; Schühlen, H.; Blasini, R.; Hadamitzky, M.; Walter, H.; Zitzmann-Roth, E.M.; Richardt, G.; Alt, E.; et al. A randomized comparison of antiplatelet and anticoagulant therapy after the placement of coronary-artery stents. N. Engl. J. Med. 1996, 334, 1084-1089. [CrossRef]

2. Leon, M.B.; Baim, D.S.; Popma, J.J.; Gordon, P.C.; Cutlip, D.E.; Ho, K.K.; Giambartolomei, A.; Diver, D.J.; Lasorda, D.M.; Williams, D.O.; et al. A clinical trial comparing three antithrombotic-drug regimens after coronary-artery stenting. Stent Anticoagulation Restenosis Study Investigators. N. Engl. J. Med. 1998, 339, 1665-1671. [CrossRef] [PubMed]

3. Yusuf, S.; Zhao, F.; Mehta, S.R.; Chrolavicius, S.; Tognoni, G.; Fox, K.K. Clopidogrel in Unstable Angina to Prevent Recurrent Events Trial Investigators Effects of clopidogrel in addition to aspirin in patients with acute coronary syndromes without ST-segment elevation. N. Engl. J. Med. 2001, 345, 494-502. [CrossRef] [PubMed] 
4. Mauri, L.; Kereiakes, D.J.; Yeh, R.W.; Driscoll-Shempp, P.; Cutlip, D.E.; Steg, P.G.; Normand, S.-L.T.; Braunwald, E.; Wiviott, S.D.; Cohen, D.J.; et al. Twelve or 30 months of dual antiplatelet therapy after drug-eluting stents. N. Engl. J. Med. 2014, 371, 2155-2166. [CrossRef] [PubMed]

5. Roffi, M.; Patrono, C.; Collet, J.-P.; Mueller, C.; Valgimigli, M.; Andreotti, F.; Bax, J.J.; Borger, M.A.; Brotons, C.; Chew, D.P.; et al. 2015 ESC Guidelines for the management of acute coronary syndromes in patients presenting without persistent ST-segment elevation: Task Force for the Management of Acute Coronary Syndromes in Patients Presenting without Persistent ST-Segment Elevation of the European Society of Cardiology (ESC). Eur. Heart J. 2016, 37, 267-315. [CrossRef]

6. Ibanez, B.; James, S.; Agewall, S.; Antunes, M.J.; Bucciarelli-Ducci, C.; Bueno, H.; Caforio, A.L.P.; Crea, F.; Goudevenos, J.A.; Halvorsen, S.; et al. 2017 ESC Guidelines for the management of acute myocardial infarction in patients presenting with ST-segment elevation. Eur. Heart J. 2018, 39, 119-177. [CrossRef] [PubMed]

7. Valgimigli, M.; Bueno, H.; Byrne, R.A.; Collet, J.-P.; Costa, F.; Jeppsson, A.; Jüni, P.; Kastrati, A.; Kolh, P.; Mauri, L.; et al. 2017 ESC focused update on dual antiplatelet therapy in coronary artery disease developed in collaboration with EACTS. Eur. Heart J. 2018, 39, 213-260. [CrossRef]

8. Wiviott, S.D.; Braunwald, E.; McCabe, C.H.; Montalescot, G.; Ruzyllo, W.; Gottlieb, S.; Neumann, F.-J.; Ardissino, D.; De Servi, S.; Murphy, S.A.; et al. Prasugrel versus Clopidogrel in Patients with Acute Coronary Syndromes. N. Engl. J. Med. 2007, 357, 2001-2015. [CrossRef]

9. Wallentin, L.; Becker, R.C.; Budaj, A.; Cannon, C.P.; Emanuelsson, H.; Held, C.; Horrow, J.; Husted, S.; James, S.; Katus, H.; et al. Ticagrelor versus clopidogrel in patients with acute coronary syndromes. N. Engl. J. Med. 2009, 361, 1045-1057. [CrossRef]

10. Roe, M.T.; Armstrong, P.W.; Fox, K.A.A.; White, H.D.; Prabhakaran, D.; Goodman, S.G.; Cornel, J.H.; Bhatt, D.L.; Clemmensen, P.; Martinez, F.; et al. Prasugrel versus Clopidogrel for Acute Coronary Syndromes without Revascularization. N. Engl. J. Med. 2012, 367, 1297-1309. [CrossRef]

11. Berwanger, O.; Lopes, R.D.; Moia, D.D.F.; Fonseca, F.A.; Jiang, L.; Goodman, S.G.; Nicholls, S.J.; Parkhomenko, A.; Averkov, O.; Tajer, C.; et al. Ticagrelor versus Clopidogrel in Patients with STEMI Treated with Fibrinolysis: TREAT Trial. J. Am. Coll. Cardiol. 2019, 73, 2819-2828. [CrossRef] [PubMed]

12. Baber, U.; Sartori, S.; Aquino, M.; Kini, A.; Kapadia, S.; Weiss, S.; Strauss, C.; Muhlestein, J.B.; Toma, C.; Rao, S.V.; et al. Use of prasugrel vs clopidogrel and outcomes in patients with acute coronary syndrome undergoing percutaneous coronary intervention in contemporary clinical practice: Results from the PROMETHEUS study. Am. Heart J. 2017, 188, 73-81. [CrossRef] [PubMed]

13. Park, D.-W.; Kwon, O.; Jang, J.-S.; Yun, S.-C.; Park, H.; Kang, D.-Y.; Ahn, J.-M.; Lee, P.H.; Lee, S.-W.; Park, S.-W.; et al. Clinically Significant Bleeding with Ticagrelor versus Clopidogrel in Korean Patients with Acute Coronary Syndromes Intended for Invasive Management: A Randomized Clinical Trial. Circulation 2019, 140, 1865-1877. [CrossRef] [PubMed]

14. Halvorsen, S.; Storey, R.F.; Rocca, B.; Sibbing, D.; Ten Berg, J.; Grove, E.L.; Weiss, T.W.; Collet, J.-P.; Andreotti, F.; Gulba, D.C.; et al. Management of antithrombotic therapy after bleeding in patients with coronary artery disease and/or atrial fibrillation: Expert consensus paper of the European Society of Cardiology Working Group on Thrombosis. Eur. Heart J. 2017, 38, 1455-1462. [CrossRef]

15. Rao, S.V.; O’Grady, K.; Pieper, K.S.; Granger, C.B.; Newby, L.K.; Mahaffey, K.W.; Moliterno, D.J.; Lincoff, A.M.; Armstrong, P.W.; Van de Werf, F; et al. A comparison of the clinical impact of bleeding measured by two different classifications among patients with acute coronary syndromes. J. Am. Coll. Cardiol. 2006, 47, 809-816. [CrossRef]

16. Eikelboom, J.W.; Mehta, S.R.; Anand, S.S.; Xie, C.; Fox, K.A.A.; Yusuf, S. Adverse impact of bleeding on prognosis in patients with acute coronary syndromes. Circulation 2006, 114, 774-782. [CrossRef]

17. Manoukian, S.V.; Feit, F.; Mehran, R.; Voeltz, M.D.; Ebrahimi, R.; Hamon, M.; Dangas, G.D.; Lincoff, A.M.; White, H.D.; Moses, J.W.; et al. Impact of major bleeding on 30-day mortality and clinical outcomes in patients with acute coronary syndromes: An analysis from the ACUITY Trial. J. Am. Coll. Cardiol. 2007, 49, 1362-1368. [CrossRef]

18. Ndrepepa, G.; Berger, P.B.; Mehilli, J.; Seyfarth, M.; Neumann, F.-J.; Schömig, A.; Kastrati, A. Periprocedural bleeding and 1-year outcome after percutaneous coronary interventions: Appropriateness of including bleeding as a component of a quadruple end point. J. Am. Coll. Cardiol. 2008, 51, 690-697. [CrossRef] 
19. Palmerini, T.; Bacchi Reggiani, L.; Della Riva, D.; Romanello, M.; Feres, F.; Abizaid, A.; Gilard, M.; Morice, M.-C.; Valgimigli, M.; Hong, M.-K.; et al. Bleeding-Related Deaths in Relation to the Duration of Dual-Antiplatelet Therapy after Coronary Stenting. J. Am. Coll. Cardiol. 2017, 69, 2011-2022. [CrossRef]

20. Valgimigli, M.; Costa, F.; Lokhnygina, Y.; Clare, R.M.; Wallentin, L.; Moliterno, D.J.; Armstrong, P.W.; White, H.D.; Held, C.; Aylward, P.E.; et al. Trade-off of myocardial infarction vs. bleeding types on mortality after acute coronary syndrome: Lessons from the Thrombin Receptor Antagonist for Clinical Event Reduction in Acute Coronary Syndrome (TRACER) randomized trial. Eur. Heart J. 2017, 38, 804-810. [CrossRef]

21. Montalescot, G.; Brieger, D.; Dalby, A.J.; Park, S.-J.; Mehran, R. Duration of Dual Antiplatelet Therapy after Coronary Stenting. J. Am. Coll. Cardiol. 2015, 66, 832-847. [CrossRef] [PubMed]

22. Baber, U.; Leisman, D.E.; Cohen, D.J.; Gibson, C.M.; Henry, T.D.; Dangas, G.; Moliterno, D.; Kini, A.; Krucoff, M.; Colombo, A.; et al. Tailoring Antiplatelet Therapy Intensity to Ischemic and Bleeding Risk: A Cost Consequence Simulation from PARIS. Circ. Cardiovasc. Qual. Outcomes 2019, 12. [CrossRef]

23. Buccheri, S.; Capodanno, D.; James, S.; Angiolillo, D.J. Bleeding after antiplatelet therapy for the treatment of acute coronary syndromes: A review of the evidence and evolving paradigms. Expert Opin. Drug Saf. 2019, 18, 1171-1189. [CrossRef]

24. Mehran, R.; Rao, S.V.; Bhatt, D.L.; Gibson, C.M.; Caixeta, A.; Eikelboom, J.; Kaul, S.; Wiviott, S.D.; Menon, V.; Nikolsky, E.; et al. Standardized Bleeding Definitions for Cardiovascular Clinical Trials: A Consensus Report from the Bleeding Academic Research Consortium. Circulation 2011, 123, 2736-2747. [CrossRef] [PubMed]

25. Urban, P.; Mehran, R.; Colleran, R.; Angiolillo, D.J.; Byrne, R.A.; Capodanno, D.; Cuisset, T.; Cutlip, D.; Eerdmans, P.; Eikelboom, J.; et al. Defining high bleeding risk in patients undergoing percutaneous coronary intervention: A consensus document from the Academic Research Consortium for High Bleeding Risk. Eur. Heart J. 2019, 40, 2632-2653. [CrossRef]

26. Rao, S.V. The conundrum of reducing ischemic and bleeding events after PCI. J. Am. Coll. Cardiol. 2015, 65, 1421-1423. [CrossRef] [PubMed]

27. Kwok, C.S.; Sherwood, M.W.; Watson, S.M.; Nasir, S.B.; Sperrin, M.; Nolan, J.; Kinnaird, T.; Kiatchoosakun, S.; Ludman, P.F.; de Belder, M.A.; et al. Blood transfusion after percutaneous coronary intervention and risk of subsequent adverse outcomes: A systematic review and meta-analysis. JACC Cardiovasc. Interv. 2015, 8, 436-446. [CrossRef] [PubMed]

28. Moalem, K.; Baber, U.; Chandrasekhar, J.; Claessen, B.E.; Sartori, S.; Aquino, M.; Dangas, G.; Iakovou, I.; Colombo, A.; Kini, A.; et al. Incidence, predictors, and outcomes of DAPT disruption due to non-compliance vs. bleeding after PCI: Insights from the PARIS Registry. Clin. Res. Cardiol. 2019, 108, 643-650. [CrossRef]

29. Reidenberg, M.M. Drug discontinuation effects are part of the pharmacology of a drug. J. Pharmacol. Exp. Ther. 2011, 339, 324-328. [CrossRef]

30. Levine, G.N.; Bates, E.R.; Bittl, J.A.; Brindis, R.G.; Fihn, S.D.; Fleisher, L.A.; Granger, C.B.; Lange, R.A.; Mack, M.J.; Mauri, L.; et al. 2016 ACC/AHA Guideline Focused Update on Duration of Dual Antiplatelet Therapy in Patients with Coronary Artery Disease: A Report of the American College of Cardiology/American Heart Association Task Force on Clinical Practice Guidelines: An Update of the 2011 ACCF/AHA/SCAI Guideline for Percutaneous Coronary Intervention, 2011 ACCF/AHA Guideline for Coronary Artery Bypass Graft Surgery, 2012 ACC/AHA/ACP/AATS/PCNA/SCAI/STS Guideline for the Diagnosis and Management of Patients with Stable Ischemic Heart Disease, 2013 ACCF/AHA Guideline for the Management of ST-Elevation Myocardial Infarction, 2014 AHA/ACC Guideline for the Management of Patients with Non-ST-Elevation Acute Coronary Syndromes, and 2014 ACC/AHA Guideline on Perioperative Cardiovascular Evaluation and Management of Patients Undergoing Noncardiac Surgery. Circulation 2016, 134, e123-e155. [CrossRef]

31. Biasco, L.; Montrasio, G.; Moccetti, M.; Pedrazzini, G. Current trends in dual antiplatelet therapy: A 2017 update. Cardiovasc. Med. 2017, 20, 169-175. [CrossRef]

32. Steg, P.G.; Huber, K.; Andreotti, F.; Arnesen, H.; Atar, D.; Badimon, L.; Bassand, J.-P.; De Caterina, R.; Eikelboom, J.A.; Gulba, D.; et al. Bleeding in acute coronary syndromes and percutaneous coronary interventions: Position paper by the Working Group on Thrombosis of the European Society of Cardiology. Eur. Heart J. 2011, 32, 1854-1864. [CrossRef]

33. Rossello, X.; Bueno, H.; Pocock, S.J.; Van de Werf, F.; Danchin, N.; Annemans, L.; Medina, J.; Zeymer, U. Predictors of all-cause mortality and ischemic events within and beyond 1 year after an acute coronary syndrome: Results from the EPICOR registry. Clin. Cardiol. 2019, 42, 111-119. [CrossRef] [PubMed] 
34. Mathews, R.; Peterson, E.D.; Chen, A.Y.; Wang, T.Y.; Chin, C.T.; Fonarow, G.C.; Cannon, C.P.; Rumsfeld, J.S.; Roe, M.T.; Alexander, K.P. In-hospital major bleeding during ST-elevation and non-ST-elevation myocardial infarction care: Derivation and validation of a model from the ACTION Registry ${ }^{\circledR}$-GWTG ${ }^{\mathrm{TM}}$. Am. J. Cardiol. 2011, 107, 1136-1143. [CrossRef]

35. Subherwal, S.; Bach, R.G.; Chen, A.Y.; Gage, B.F.; Rao, S.V.; Newby, L.K.; Wang, T.Y.; Gibler, W.B.; Ohman, E.M.; Roe, M.T.; et al. Baseline risk of major bleeding in non-ST-segment-elevation myocardial infarction: The CRUSADE (Can Rapid risk stratification of Unstable angina patients Suppress ADverse outcomes with Early implementation of the ACC/AHA Guidelines) Bleeding Score. Circulation 2009, 119, 1873-1882. [CrossRef]

36. Mehran, R.; Pocock, S.J.; Nikolsky, E.; Clayton, T.; Dangas, G.D.; Kirtane, A.J.; Parise, H.; Fahy, M.; Manoukian, S.V.; Feit, F.; et al. A risk score to predict bleeding in patients with acute coronary syndromes. J. Am. Coll. Cardiol. 2010, 55, 2556-2566. [CrossRef]

37. Baber, U.; Mehran, R.; Giustino, G.; Cohen, D.J.; Henry, T.D.; Sartori, S.; Ariti, C.; Litherland, C.; Dangas, G.; Gibson, C.M.; et al. Coronary Thrombosis and Major Bleeding after PCI With Drug-Eluting Stents: Risk Scores from PARIS. J. Am. Coll. Cardiol. 2016, 67, 2224-2234. [CrossRef]

38. Costa, F.; van Klaveren, D.; James, S.; Heg, D.; Räber, L.; Feres, F.; Pilgrim, T.; Hong, M.-K.; Kim, H.-S.; Colombo, A.; et al. Derivation and validation of the predicting bleeding complications in patients undergoing stent implantation and subsequent dual antiplatelet therapy (PRECISE-DAPT) score: A pooled analysis of individual-patient datasets from clinical trials. Lancet 2017, 389, 1025-1034. [CrossRef]

39. Raposeiras-Roubín, S.; Faxén, J.; Íñiguez-Romo, A.; Henriques, J.P.S.; D’Ascenzo, F.; Saucedo, J.; Szummer, K.; Jernberg, T.; James, S.K.; Juanatey, J.R.G.; et al. Development and external validation of a post-discharge bleeding risk score in patients with acute coronary syndrome: The BleeMACS score. Int. J. Cardiol. 2018, 254, 10-15. [CrossRef]

40. Capodanno, D.; Angiolillo, D.J. Pretreatment with Antiplatelet Drugs in Invasively Managed Patients with Coronary Artery Disease in the Contemporary Era: Review of the Evidence and Practice Guidelines. Circ. Cardiovasc. Interv. 2015, 8. [CrossRef]

41. Capodanno, D.; Angiolillo, D.J. Pre-Treatment with Oral P2Y12 Inhibitors in Acute Coronary Syndromes without ST-Segment Elevation. J. Am. Coll. Cardiol. 2019, 73, 915-918. [CrossRef] [PubMed]

42. Koul, S.; Smith, J.G.; Scherstén, F.; James, S.; Lagerqvist, B.; Erlinge, D. Effect of upstream clopidogrel treatment in patients with ST-segment elevation myocardial infarction undergoing primary percutaneous coronary intervention. Eur. Heart J. 2011, 32, 2989-2997. [CrossRef] [PubMed]

43. Dörler, J.; Edlinger, M.; Alber, H.F.; Altenberger, J.; Benzer, W.; Grimm, G.; Huber, K.; Pachinger, O.; Schuchlenz, H.; Siostrzonek, P.; et al. Clopidogrel pre-treatment is associated with reduced in-hospital mortality in primary percutaneous coronary intervention for acute ST-elevation myocardial infarction. Eur. Heart J. 2011, 32, 2954-2961. [CrossRef] [PubMed]

44. Zeymer, U.; Arntz, H.-R.; Mark, B.; Fichtlscherer, S.; Werner, G.; Schöller, R.; Zahn, R.; Diller, F.; Darius, H.; Dill, T.; et al. Efficacy and safety of a high loading dose of clopidogrel administered prehospitally to improve primary percutaneous coronary intervention in acute myocardial infarction: The randomized CIPAMI trial. Clin. Res. Cardiol. 2012, 101, 305-312. [CrossRef] [PubMed]

45. Montalescot, G.; van 't Hof, A.W.; Lapostolle, F.; Silvain, J.; Lassen, J.F.; Bolognese, L.; Cantor, W.J.; Cequier, A.; Chettibi, M.; Goodman, S.G.; et al. Prehospital ticagrelor in ST-segment elevation myocardial infarction. N. Engl. J. Med. 2014, 371, 1016-1027. [CrossRef]

46. Redfors, B.; Dworeck, C.; Haraldsson, I.; Angerås, O.; Odenstedt, J.; Ioanes, D.; Petursson, P.; Völz, S.; Albertsson, P.; Råmunddal, T.; et al. Pretreatment with P2Y12 receptor antagonists in ST-elevation myocardial infarction: A report from the Swedish Coronary Angiography and Angioplasty Registry. Eur. Heart J. 2019, 40, 1202-1210. [CrossRef]

47. Montalescot, G.; Bolognese, L.; Dudek, D.; Goldstein, P.; Hamm, C.; Tanguay, J.-F.; ten Berg, J.M.; Miller, D.L.; Costigan, T.M.; Goedicke, J.; et al. Pretreatment with Prasugrel in Non-ST-Segment Elevation Acute Coronary Syndromes. N. Engl. J. Med. 2013, 369, 999-1010. [CrossRef]

48. Silvain, J.; Rakowski, T.; Lattuca, B.; Liu, Z.; Bolognese, L.; Goldstein, P.; Hamm, C.; Tanguay, J.-F.; ten Berg, J.; Widimsky, P.; et al. Interval from Initiation of Prasugrel to Coronary Angiography in Patients with Non-ST-Segment Elevation Myocardial Infarction. J. Am. Coll. Cardiol. 2019, 73, 906-914. [CrossRef] 
49. Omerovic, E. Report from SCAAR: Pretreatment with P2Y12 receptor antagonists is not associated with improved clinical outcomes in UA/NSTEMI. In Proceedings of the ESC 2018, Munich, Germany, 28 August 2018.

50. Valgimigli, M.; Gagnor, A.; Calabró, P.; Frigoli, E.; Leonardi, S.; Zaro, T.; Rubartelli, P.; Briguori, C.; Andò, G.; Repetto, A.; et al. Radial versus femoral access in patients with acute coronary syndromes undergoing invasive management: A randomised multicentre trial. Lancet 2015, 385, 2465-2476. [CrossRef]

51. Ferrante, G.; Rao, S.V.; Jüni, P.; Da Costa, B.R.; Reimers, B.; Condorelli, G.; Anzuini, A.; Jolly, S.S.; Bertrand, O.F.; Krucoff, M.W.; et al. Radial versus Femoral Access for Coronary Interventions across the Entire Spectrum of Patients with Coronary Artery Disease: A Meta-Analysis of Randomized Trials. JACC Cardiovasc. Interv. 2016, 9, 1419-1434. [CrossRef] [PubMed]

52. Neumann, F.-J.; Sousa-Uva, M.; Ahlsson, A.; Alfonso, F.; Banning, A.P.; Benedetto, U.; Byrne, R.A.; Collet, J.-P.; Falk, V.; Head, S.J.; et al. 2018 ESC/EACTS Guidelines on myocardial revascularization. Eur. Heart J. 2019, 40, 87-165. [CrossRef]

53. Valgimigli, M.; Ariotti, S.; Costa, F. Duration of dual antiplatelet therapy after drug-eluting stent implantation: Will we ever reach a consensus? Eur. Heart J. 2015, 36, 1219-1222. [CrossRef] [PubMed]

54. Yeh, R.W.; Mihatov, N. The DAPT Score Uncouples Bleeding and Ischemic Risk... Again. JACC Cardiovasc. Interv. 2020, 13, 647-650. [CrossRef] [PubMed]

55. Valgimigli, M.; Costa, F.; Byrne, R.; Haude, M.; Baumbach, A.; Windecker, S. Dual antiplatelet therapy duration after coronary stenting in clinical practice: Results of an EAPCI survey. EuroIntervention 2015, 11, 68-74. [CrossRef]

56. Motovska, Z.; Hlinomaz, O.; Miklik, R.; Hromadka, M.; Varvarovsky, I.; Dusek, J.; Knot, J.; Jarkovsky, J.; Kala, P.; Rokyta, R.; et al. Prasugrel versus Ticagrelor in Patients with Acute Myocardial Infarction Treated with Primary Percutaneous Coronary Intervention: Multicenter Randomized PRAGUE-18 Study. Circulation 2016, 134, 1603-1612. [CrossRef] [PubMed]

57. Schüpke, S.; Neumann, F.-J.; Menichelli, M.; Mayer, K.; Bernlochner, I.; Wöhrle, J.; Richardt, G.; Liebetrau, C.; Witzenbichler, B.; Antoniucci, D.; et al. Ticagrelor or Prasugrel in Patients with Acute Coronary Syndromes. N. Engl. J. Med. 2019, 381, 1524-1534. [CrossRef] [PubMed]

58. Bonaca, M.P.; Bhatt, D.L.; Cohen, M.; Steg, P.G.; Storey, R.F.; Jensen, E.C.; Magnani, G.; Bansilal, S.; Fish, M.P.; Im, K.; et al. Long-Term Use of Ticagrelor in Patients with Prior Myocardial Infarction. N. Engl. J. Med. 2015, 372, 1791-1800. [CrossRef] [PubMed]

59. Costa, F.; Van Klaveren, D.; Feres, F.; James, S.; Räber, L.; Pilgrim, T.; Hong, M.-K.; Kim, H.-S.; Colombo, A.; Steg, P.G.; et al. Dual Antiplatelet Therapy Duration Based on Ischemic and Bleeding Risks after Coronary Stenting. J. Am. Coll. Cardiol. 2019, 73, 741-754. [CrossRef]

60. Mehran, R.; Baber, U.; Sharma, S.K.; Cohen, D.J.; Angiolillo, D.J.; Briguori, C.; Cha, J.Y.; Collier, T.; Dangas, G.; Dudek, D.; et al. Ticagrelor with or without Aspirin in High-Risk Patients after PCI. N. Engl. J. Med. 2019, 381, 2032-2042. [CrossRef]

61. Vranckx, P.; Valgimigli, M.; Jüni, P.; Hamm, C.; Steg, P.G.; Heg, D.; van Es, G.A.; McFadden, E.P.; Onuma, Y.; van Meijeren, C.; et al. Ticagrelor plus aspirin for 1 month, followed by ticagrelor monotherapy for 23 months vs aspirin plus clopidogrel or ticagrelor for 12 months, followed by aspirin monotherapy for 12 months after implantation of a drug-eluting stent: A multicentre, open-label, randomised superiority trial. Lancet 2018, 392, 940-949. [CrossRef]

62. Kim, B.-K.; Hong, S.-J.; Cho, Y.-H.; Yun, K.H.; Kim, Y.H.; Suh, Y.; Cho, J.Y.; Her, A.-Y.; Cho, S.; Jeon, D.W.; et al. Effect of Ticagrelor Monotherapy vs Ticagrelor with Aspirin on Major Bleeding and Cardiovascular Events in Patients with Acute Coronary Syndrome: The TICO Randomized Clinical Trial. JAMA 2020, 323, 2407. [CrossRef]

63. Komen, J.J.; Forslund, T.; Mantel-Teeuwisse, A.K.; Klungel, O.H.; von Euler, M.; Braunschweig, F.; Wallén, H.; Hjemdahl, P. Association of Preceding Antithrombotic Therapy in Atrial Fibrillation Patients with Ischemic Stroke, Intracranial Hemorrhage, or Gastrointestinal Bleed and Mortality. Eur. Heart J. Cardiovasc. Pharmacother 2019. [CrossRef] [PubMed]

64. Franco, L.; Paciaroni, M.; Enrico, M.L.; Scoditti, U.; Guideri, F.; Chiti, A.; De Vito, A.; Terruso, V.; Consoli, D.; Vanni, S.; et al. Mortality in patients with intracerebral hemorrhage associated with antiplatelet agents, oral anticoagulants or no antithrombotic therapy. Eur. J. Intern. Med. 2020, 75, 35-43. [CrossRef] [PubMed] 
65. Roquer, J.; Vivanco Hidalgo, R.M.; Ois, A.; Rodríguez Campello, A.; Cuadrado Godia, E.; Giralt Steinhauer, E.; Gómez González, A.; Soriano-Tarraga, C.; Jiménez Conde, J. Antithrombotic pretreatment increases very-early mortality in primary intracerebral hemorrhage. Neurology 2017, 88, 885-891. [CrossRef] [PubMed]

66. Battle, C.; Hutchings, H.; Bouamra, O.; Evans, P.A. The Effect of Pre-Injury Anti-Platelet Therapy on the Development of Complications in Isolated Blunt Chest Wall Trauma: A Retrospective Study. PLoS ONE 2014, 9, e91284. [CrossRef]

67. Rao, S.V.; O'Grady, K.; Pieper, K.S.; Granger, C.B.; Newby, L.K.; Van de Werf, F.; Mahaffey, K.W.; Califf, R.M.; Harrington, R.A. Impact of bleeding severity on clinical outcomes among patients with acute coronary syndromes. Am. J. Cardiol. 2005, 96, 1200-1206. [CrossRef]

68. Généreux, P.; Giustino, G.; Witzenbichler, B.; Weisz, G.; Stuckey, T.D.; Rinaldi, M.J.; Neumann, F.-J.; Metzger, D.C.; Henry, T.D.; Cox, D.A.; et al. Incidence, Predictors, and Impact of Post-Discharge Bleeding after Percutaneous Coronary Intervention. J. Am. Coll. Cardiol. 2015, 66, 1036-1045. [CrossRef]

69. Becker, R.C.; Bassand, J.P.; Budaj, A.; Wojdyla, D.M.; James, S.K.; Cornel, J.H.; French, J.; Held, C.; Horrow, J.; Husted, S.; et al. Bleeding complications with the P2Y12 receptor antagonists clopidogrel and ticagrelor in the PLATelet inhibition and patient Outcomes (PLATO) trial. Eur. Heart J. 2011, 32, 2933-2944. [CrossRef]

70. Ma, L.; Elliott, S.N.; Cirino, G.; Buret, A.; Ignarro, L.J.; Wallace, J.L. Platelets modulate gastric ulcer healing: Role of endostatin and vascular endothelial growth factor release. Proc. Natl. Acad. Sci. USA 2001, 98, 6470-6475. [CrossRef]

71. Nikolsky, E.; Stone, G.W.; Kirtane, A.J.; Dangas, G.D.; Lansky, A.J.; McLaurin, B.; Lincoff, A.M.; Feit, F.; Moses, J.W.; Fahy, M.; et al. Gastrointestinal bleeding in patients with acute coronary syndromes: Incidence, predictors, and clinical implications: Analysis from the ACUITY (Acute Catheterization and Urgent Intervention Triage Strategy) trial. J. Am. Coll. Cardiol. 2009, 54, 1293-1302. [CrossRef] [PubMed]

72. Zuccaro, G. Epidemiology of lower gastrointestinal bleeding. Best Pract. Res. Clin. Gastroenterol. 2008, 22, 225-232. [CrossRef]

73. Ramaswamy, R.S.; Choi, H.W.; Mouser, H.C.; Narsinh, K.H.; McCammack, K.C.; Treesit, T.; Kinney, T.B. Role of interventional radiology in the management of acute gastrointestinal bleeding. World J. Radiol. 2014, 6, 82-92. [CrossRef] [PubMed]

74. Darcy, M. Treatment of lower gastrointestinal bleeding: Vasopressin infusion versus embolization. J. Vasc. Interv. Radiol. 2003, 14, 535-543. [CrossRef] [PubMed]

75. Bush, H.L.; Nabseth, D.C. Intravenous nitroglycerin to improve coronary blood flow and left ventricular performance during vasopressin therapy. Surg. Forum 1979, 30, 226-228.

76. Junquera, F.; Saperas, E.; Videla, S.; Feu, F.; Vilaseca, J.; Armengol, J.R.; Bordas, J.M.; Piqué, J.M.; Malagelada, J.-R. Long-term efficacy of octreotide in the prevention of recurrent bleeding from gastrointestinal angiodysplasia. Am. J. Gastroenterol. 2007, 102, 254-260. [CrossRef]

77. Gralnek, I.; Dumonceau, J.-M.; Kuipers, E.; Lanas, A.; Sanders, D.; Kurien, M.; Rotondano, G.; Hucl, T.; Dinis-Ribeiro, M.; Marmo, R.; et al. Diagnosis and management of nonvariceal upper gastrointestinal hemorrhage: European Society of Gastrointestinal Endoscopy (ESGE) Guideline. Endoscopy 2015, 47, a1-a46. [CrossRef]

78. Strate, L.L.; Gralnek, I.M. ACG Clinical Guideline: Management of Patients with Acute Lower Gastrointestinal Bleeding. Am. J. Gastroenterol. 2016, 111, 459-474. [CrossRef]

79. Sehested, T.S.G.; Carlson, N.; Hansen, P.W.; Gerds, T.A.; Charlot, M.G.; Torp-Pedersen, C.; Køber, L.; Gislason, G.H.; Hlatky, M.A.; Fosbøl, E.L. Reduced risk of gastrointestinal bleeding associated with proton pump inhibitor therapy in patients treated with dual antiplatelet therapy after myocardial infarction. Eur. Heart J. 2019, 40, 1963-1970. [CrossRef]

80. Biffi, A.; Halpin, A.; Towfighi, A.; Gilson, A.; Busl, K.; Rost, N.; Smith, E.E.; Greenberg, M.S.; Rosand, J.; Viswanathan, A. Aspirin and recurrent intracerebral hemorrhage in cerebral amyloid angiopathy. Neurology 2010, 75, 693-698. [CrossRef]

81. Baharoglu, M.I.; Cordonnier, C.; Al-Shahi Salman, R.; de Gans, K.; Koopman, M.M.; Brand, A.; Majoie, C.B.; Beenen, L.F.; Marquering, H.A.; Vermeulen, M.; et al. Platelet transfusion versus standard care after acute stroke due to spontaneous cerebral haemorrhage associated with antiplatelet therapy (PATCH): A randomised, open-label, phase 3 trial. Lancet 2016, 387, 2605-2613. [CrossRef] 
82. Connolly, E.S.; Rabinstein, A.A.; Carhuapoma, J.R.; Derdeyn, C.P.; Dion, J.; Higashida, R.T.; Hoh, B.L.; Kirkness, C.J.; Naidech, A.M.; Ogilvy, C.S.; et al. Guidelines for the management of aneurysmal subarachnoid hemorrhage: A guideline for healthcare professionals from the American Heart Association/american Stroke Association. Stroke 2012, 43, 1711-1737. [CrossRef]

83. Gimbel, M.E.; Minderhoud, S.C.S.; ten Berg, J.M. A practical guide on how to handle patients with bleeding events while on oral antithrombotic treatment. Neth. Heart J. 2018, 26, 341-351. [CrossRef] [PubMed]

84. Ding, X.; Liu, X.; Tan, C.; Yin, M.; Wang, T.; Liu, Y.; Mo, L.; Wei, X.; Tan, X.; Deng, F.; et al. Resumption of antiplatelet therapy in patients with primary intracranial hemorrhage-benefits and risks: A meta-analysis of cohort studies. J. Neurol. Sci. 2018, 384, 133-138. [CrossRef] [PubMed]

85. Eisenberg, M.J.; Richard, P.R.; Libersan, D.; Filion, K.B. Safety of short-term discontinuation of antiplatelet therapy in patients with drug-eluting stents. Circulation 2009, 119, 1634-1642. [CrossRef]

86. van Werkum, J.W.; Heestermans, A.A.; Zomer, A.C.; Kelder, J.C.; Suttorp, M.-J.; Rensing, B.J.; Koolen, J.J.; Brueren, B.R.G.; Dambrink, J.-H.E.; Hautvast, R.W.; et al. Predictors of coronary stent thrombosis: The Dutch Stent Thrombosis Registry. J. Am. Coll. Cardiol. 2009, 53, 1399-1409. [CrossRef]

87. Park, D.-W.; Park, S.-W.; Park, K.-H.; Lee, B.-K.; Kim, Y.-H.; Lee, C.W.; Hong, M.-K.; Kim, J.-J.; Park, S.-J. Frequency of and risk factors for stent thrombosis after drug-eluting stent implantation during long-term follow-up. Am. J. Cardiol. 2006, 98, 352-356. [CrossRef]

88. Price, M.J.; Walder, J.S.; Baker, B.A.; Heiselman, D.E.; Jakubowski, J.A.; Logan, D.K.; Winters, K.J.; Li, W.; Angiolillo, D.J. Recovery of platelet function after discontinuation of prasugrel or clopidogrel maintenance dosing in aspirin-treated patients with stable coronary disease: The recovery trial. J. Am. Coll. Cardiol. 2012, 59, 2338-2343. [CrossRef]

89. Dobesh, P.P.; Oestreich, J.H. Ticagrelor: Pharmacokinetics, pharmacodynamics, clinical efficacy, and safety. Pharmacotherapy 2014, 34, 1077-1090. [CrossRef]

90. Franchi, F.; Rollini, F.; Park, Y.; Angiolillo, D.J. Novel Antiplatelet Agents: The Current State and What Is Coming Down the Pike. Prog. Cardiovasc. Dis. 2015, 58, 267-277. [CrossRef]

91. Iakovou, I.; Schmidt, T.; Bonizzoni, E.; Ge, L.; Sangiorgi, G.M.; Stankovic, G.; Airoldi, F.; Chieffo, A.; Montorfano, M.; Carlino, M.; et al. Incidence, predictors, and outcome of thrombosis after successful implantation of drug-eluting stents. JAMA 2005, 293, 2126-2130. [CrossRef]

92. Veitch, A.M.; Vanbiervliet, G.; Gershlick, A.H.; Boustiere, C.; Baglin, T.P.; Smith, L.-A.; Radaelli, F.; Knight, E.; Gralnek, I.M.; Hassan, C.; et al. Endoscopy in patients on antiplatelet or anticoagulant therapy, including direct oral anticoagulants: British Society of Gastroenterology (BSG) and European Society of Gastrointestinal Endoscopy (ESGE) guidelines. Endoscopy 2016, 48, 385-402. [CrossRef] [PubMed]

93. Mehran, R.; Baber, U.; Steg, P.G.; Ariti, C.; Weisz, G.; Witzenbichler, B.; Henry, T.D.; Kini, A.S.; Stuckey, T.; Cohen, D.J.; et al. Cessation of dual antiplatelet treatment and cardiac events after percutaneous coronary intervention (PARIS): 2 year results from a prospective observational study. Lancet 2013, 382, 1714-1722. [CrossRef]

94. Palmerini, T.; Benedetto, U.; Bacchi-Reggiani, L.; Della Riva, D.; Biondi-Zoccai, G.; Feres, F.; Abizaid, A.; Hong, M.-K.; Kim, B.-K.; Jang, Y.; et al. Mortality in patients treated with extended duration dual antiplatelet therapy after drug-eluting stent implantation: A pairwise and Bayesian network meta-analysis of randomised trials. Lancet 2015, 385, 2371-2382. [CrossRef]

95. Yin, S.-H.-L.; Xu, P.; Wang, B.; Lu, Y.; Wu, Q.-Y.; Zhou, M.-L.; Wu, J.-R.; Cai, J.-J.; Sun, X.; Yuan, H. Duration of dual antiplatelet therapy after percutaneous coronary intervention with drug-eluting stent: Systematic review and network meta-analysis. BMJ 2019, 365, 12222. [CrossRef] [PubMed]

96. Feres, F.; Costa, R.A.; Abizaid, A.; Leon, M.B.; Marin-Neto, J.A.; Botelho, R.V.; King, S.B.; Negoita, M.; Liu, M.; de Paula, J.E.T.; et al. Three vs twelve months of dual antiplatelet therapy after zotarolimus-eluting stents: The OPTIMIZE randomized trial. JAMA 2013, 310, 2510-2522. [CrossRef] [PubMed]

97. De Luca, G.; Damen, S.A.; Camaro, C.; Benit, E.; Verdoia, M.; Rasoul, S.; Liew, H.B.; Polad, J.; Ahmad, W.A.; Zambahari, R.; et al. Final results of the randomised evaluation of short-term dual antiplatelet therapy in patients with acute coronary syndrome treated with a new-generation stent (REDUCE trial). EuroIntervention 2019, 15, e990-e998. [CrossRef] 
98. Kim, B.-K.; Hong, M.-K.; Shin, D.-H.; Nam, C.-M.; Kim, J.-S.; Ko, Y.-G.; Choi, D.; Kang, T.-S.; Park, B.-E.; Kang, W.-C.; et al. A new strategy for discontinuation of dual antiplatelet therapy: The RESET Trial (REal Safety and Efficacy of 3-month dual antiplatelet Therapy following Endeavor zotarolimus-eluting stent implantation). J. Am. Coll. Cardiol. 2012, 60, 1340-1348. [CrossRef]

99. Hahn, J.-Y.; Song, Y.B.; Oh, J.-H.; Chun, W.J.; Park, Y.H.; Jang, W.J.; Im, E.-S.; Jeong, J.-O.; Cho, B.R.; Oh, S.K.; et al. Effect of P2Y12 Inhibitor Monotherapy vs Dual Antiplatelet Therapy on Cardiovascular Events in Patients Undergoing Percutaneous Coronary Intervention: The SMART-CHOICE Randomized Clinical Trial. JAMA 2019, 321, 2428. [CrossRef]

100. Watanabe, H.; Domei, T.; Morimoto, T.; Natsuaki, M.; Shiomi, H.; Toyota, T.; Ohya, M.; Suwa, S.; Takagi, K.; Nanasato, M.; et al. Effect of 1-Month Dual Antiplatelet Therapy Followed by Clopidogrel vs 12-Month Dual Antiplatelet Therapy on Cardiovascular and Bleeding Events in Patients Receiving PCI: The STOPDAPT-2 Randomized Clinical Trial. JAMA 2019, 321, 2414. [CrossRef]

101. Benenati, S.; Galli, M.; De Marzo, V.; Pescetelli, F.; Toma, M.; Andreotti, F.; Bona, R.D.; Canepa, M.; Ameri, P.; Crea, F.; et al. Very Short vs. Long Dual Antiplatelet Therapy after Second Generation Drug-eluting Stents in 35,785 Patients undergoing Percutaneous Coronary Interventions: A Meta-analysis of Randomised Controlled Trials. Eur. Heart J. Cardiovasc. Pharmacother 2020. [CrossRef]

102. Windecker, S.; Latib, A.; Kedhi, E.; Kirtane, A.J.; Kandzari, D.E.; Mehran, R.; Price, M.J.; Abizaid, A.; Simon, D.I.; Worthley, S.G.; et al. Polymer-based or Polymer-free Stents in Patients at High Bleeding Risk. N. Engl. J. Med. 2020, 382, 1208-1218. [CrossRef]

103. De Luca, L.; D’Ascenzo, F.; Musumeci, G.; Saia, F.; Parodi, G.; Varbella, F.; Marchese, A.; De Servi, S.; Berti, S.; Bolognese, L. Incidence and outcome of switching of oral platelet P2Y12 receptor inhibitors in patients with acute coronary syndromes undergoing percutaneous coronary intervention: The SCOPE registry. EuroIntervention 2017, 13, 459-466. [CrossRef] [PubMed]

104. Cuisset, T.; Deharo, P.; Quilici, J.; Johnson, T.W.; Deffarges, S.; Bassez, C.; Bonnet, G.; Fourcade, L.; Mouret, J.P.; Lambert, M.; et al. Benefit of switching dual antiplatelet therapy after acute coronary syndrome: The TOPIC (timing of platelet inhibition after acute coronary syndrome) randomized study. Eur. Heart J. 2017, 38, 3070-3078. [CrossRef]

105. Gurbel, P.A.; Bliden, K.P.; Hiatt, B.L.; O'Connor, C.M. Clopidogrel for coronary stenting: Response variability, drug resistance, and the effect of pretreatment platelet reactivity. Circulation 2003, 107, 2908-2913. [CrossRef] [PubMed]

106. Geisler, T.; Grass, D.; Bigalke, B.; Stellos, K.; Drosch, T.; Dietz, K.; Herdeg, C.; Gawaz, M. The Residual Platelet Aggregation after Deployment of Intracoronary Stent (PREDICT) score. J. Thromb. Haemost. 2008, 6, 54-61. [CrossRef] [PubMed]

107. Fontana, P.; Berdagué, P.; Castelli, C.; Nolli, S.; Barazer, I.; Fabbro-Peray, P.; Schved, J.-F.; Bounameaux, H.; Mach, F.; DE Moerloose, P.; et al. Clinical predictors of dual aspirin and clopidogrel poor responsiveness in stable cardiovascular patients from the ADRIE study. J. Thromb. Haemost. 2010, 8, 2614-2623. [CrossRef] [PubMed]

108. Storelli, F.; Daali, Y.; Desmeules, J.; Reny, J.-L.; Fontana, P. Pharmacogenomics of Oral Antithrombotic Drugs. Curr. Pharm. Des. 2016, 22, 1933-1949. [CrossRef]

109. Lewis, J.P.; Backman, J.D.; Reny, J.-L.; Bergmeijer, T.O.; Mitchell, B.D.; Ritchie, M.D.; Déry, J.-P.; Pakyz, R.E.; Gong, L.; Ryan, K.; et al. Pharmacogenomic Polygenic Response Score Predicts Ischemic Events and Cardiovascular Mortality in Clopidogrel-Treated Patients. Eur. Heart J. Cardiovasc. Pharmacother. 2019. [CrossRef]

110. Sibbing, D.; Aradi, D.; Alexopoulos, D.; Ten Berg, J.; Bhatt, D.L.; Bonello, L.; Collet, J.-P.; Cuisset, T.; Franchi, F.; Gross, L.; et al. Updated Expert Consensus Statement on Platelet Function and Genetic Testing for Guiding P2Y12 Receptor Inhibitor Treatment in Percutaneous Coronary Intervention. JACC Cardiovasc. Interv. 2019, 12, 1521-1537. [CrossRef]

111. Armstrong, P.C.J.; Leadbeater, P.D.; Chan, M.V.; Kirkby, N.S.; Jakubowski, J.A.; Mitchell, J.A.; Warner, T.D. In the presence of strong P2Y12 receptor blockade, aspirin provides little additional inhibition of platelet aggregation. J. Thromb. Haemost. 2011, 9, 552-561. [CrossRef] [PubMed]

112. Traby, L.; Kollars, M.; Kaider, A.; Siller-Matula, J.M.; Wolkersdorfer, M.F.; Wolzt, M.; Kyrle, P.A.; Eichinger, S. Differential Effects of Ticagrelor with or without Aspirin on Platelet Reactivity and Coagulation Activation: A Randomized Trial in Healthy Volunteers. Clin. Pharmacol. Ther. 2020, 107, 415-422. [CrossRef] [PubMed] 
113. Hansen, M.L.; Sørensen, R.; Clausen, M.T.; Fog-Petersen, M.L.; Raunsø, J.; Gadsbøll, N.; Gislason, G.H.; Folke, F.; Andersen, S.S.; Schramm, T.K.; et al. Risk of bleeding with single, dual, or triple therapy with warfarin, aspirin, and clopidogrel in patients with atrial fibrillation. Arch. Intern. Med. 2010, 170, 1433-1441. [CrossRef] [PubMed]

114. Oldgren, J.; Budaj, A.; Granger, C.B.; Khder, Y.; Roberts, J.; Siegbahn, A.; Tijssen, J.G.P.; Van de Werf, F.; Wallentin, L. RE-DEEM Investigators Dabigatran vs. placebo in patients with acute coronary syndromes on dual antiplatelet therapy: A randomized, double-blind, phase II trial. Eur. Heart J. 2011, 32, 2781-2789. [CrossRef]

(C) 2020 by the authors. Licensee MDPI, Basel, Switzerland. This article is an open access article distributed under the terms and conditions of the Creative Commons Attribution (CC BY) license (http://creativecommons.org/licenses/by/4.0/). 